\title{
Monetary Policy Cooperation/Coordination and Global Financial Crises in Historical Perspective
}

\author{
Michael David Bordo ${ }^{1,2,3}$
}

Accepted: 2 December 2020/Published online: 29 January 2021

(C) The Author(s), under exclusive licence to Springer Science+Business Media, LLC part of Springer Nature 2021

\begin{abstract}
The Covid 19 pandemic spawned a global liquidity crisis in March 2020. The global liquidity crisis was alleviated by the Federal Reserve and other advanced country central banks cooperating by extending the swap lines they developed in the Global Financial Crisis 2007-2008. Central bank cooperation in 2020 evolved from a two-century history across several monetary regimes that is surveyed in this paper. I find that in monetary regimes which are rules-based cooperation was most successful. International currency swaps developed to manage exchange rates during the Bretton Woods era have evolved into the leading tool to manage international liquidity crises. The swap network can be viewed as a step in the direction of a global financial safety net.
\end{abstract}

Keywords Central bank cooperation $\cdot$ Policy coordination $\cdot$ Swap $\cdot$ Rules

JEL Codes E58 $\cdot \mathrm{F} 33 \cdot \mathrm{N} 20$

\section{Introduction}

We are currently in the midst of the global Covid 19 pandemic which is ravaging both advanced and emerging countries. Unless an effective vaccine is adopted we will follow the path of the 1918 Spanish flu pandemic and not be out of the woods for another year.

Paper prepared for the conference "From Bretton Woods to 2008 and Beyond: Global Monetary Governance" Brussels, Belgium September 182020

Michael David Bordo

bordo@econ.rutgers.edu

1 University of Chicago, 60637, Chicago, IL 1972, USA

2 Rutgers University, New Brunswick, NJ, USA

3 National Bureau of Economic Research,Distinguished Visiting Fellow, Hoover Institution, Stanford University, Stanford, CA 94305, USA 
The advent of the pandemic in Europe and the U.S. in March 2020 led to a global financial crisis once most countries locked down their economies. The crisis has a number of dimensions including: domestic liquidity; international liquidity; a sudden stop; sovereign debt default; a most serious recession and challenges to the global monetary order. So far, the domestic and international liquidity crises have been well managed by central banks following tried and true policies.

The recent experience of successful central bank cooperation evolved from a two century history that I describe in this paper. ${ }^{1}$ By central bank cooperation is meant: lender of last resort actions; the sharing of information and techniques of central banking and the discovery of common problems. By coordination is meant policy actions formally agreed upon and taken by groups of policy makers to achieve beneficial outcomes for the international monetary system as a whole.

I first survey the history of central bank cooperation and coordination across historical regimes: the classical gold standard 1880-1914; the interwar gold exchange standard 1924-1939; the Bretton Woods System 1944-1973; and the present fiat money managed floating exchange rate regime. With this background I then focus on the two recent global financial crises: the Global Financial Crisis (GFC) of 2007-2008; and the current Covid 19 pandemic since March 2020.

The key lessons from the historical survey are:

1) Monetary policy cooperation is successful when done in a rules-based environment e.g. the classical gold standard 1880-1914 and the Great Moderation 1985-2006.

2) Monetary Policy Cooperation is less successful when either the rules do not work or they are not followed, e.g. the interwar gold exchange standard, the Bretton Woods system, the 1970 s and 1980 s.

3) Monetary policy coordination does not work well when it involves a departure from domestic policy fundamentals, e.g. the 1927 Long Island meeting between the governors of the core country central bankers.

4) The coordinated rescues of the emerging market countries in the financial crises of the 1990s were mainly bailouts and not based on Walter Bagehot's famous principles.

5) Central bank cooperation arranged through the Bank for International Settlements (BIS) helped to create an epistemic community which has learned to follow rulesbased policy.

6) International currency swaps developed to manage exchange rates in the Bretton Woods period have evolved during the Global Financial Crisis of 2007-2008 and the current crisis in 2020 into the leading tool to manage international liquidity crises.

\section{The History of Central Bank Cooperation/Coordination}

\subsection{The Classical Gold Standard 1880-1914}

The classical gold standard was the original rules based monetary policy regime (Bordo and Kydland 1995). The basic rule for each monetary authority was to maintain

\footnotetext{
${ }^{1}$ See Bordo and Schenk (2016)
} 
convertibility of its paper currency in terms of gold at the official nominal price (or as a fixed number of ounces of gold). This required subsuming domestic policy goals to the dictates of external balance panic.

Central banks in advanced countries before 1914 did consistently follow the convertibility rule (except during wartime emergencies and serious banking panics when they suspended convertibility). To the extent that central banks adhered to the gold standard rule of convertibility they implicitly cooperated.

Cooperation during the gold standard was quite limited. To the extent that central banks adhered to the gold standard they implicitly cooperated. Even the minor violations of the gold points that occurred were never sufficient to threaten the international monetary system.

There is evidence that in the face of several large financial crises (e.g. 1890 and 1907) the Banque de France, which had very large gold reserves, lent gold on commercial terms to the Bank of England, to allow it to avoid suspending convertibility. Some argue that that this cooperation was essential to the survival of the gold standard (Borio and Toniolo 2005; Eichengreen 1992) but the evidence suggests otherwise (Flandreau 1987 and Bordo and Schwartz 1999).

The Bank of England held a 'thin film of gold' because it had a long record of credibility which ensured that capital flows would be stabilizing. Moreover, in financial crises which did not involve rescue loans the Bank requested a 'Treasury Letter' allowing it to temporarily suspend convertibility. When this happened, as in 1825 and 1847 , the panic ended.

Finally, several early unsuccessful attempts at international monetary coordination occurred at a number of conferences (in Paris 1867 and 1878) held to try to standardize gold coins across the major countries foundered on the rocks of sovereignty. Later in the century, at the height of the Free Silver movement, a number of international conferences were held in the US to promote global bimetallism. Nothing came out of them.

The gold standard was successful because it was rules based and each member voluntarily adhered to the convertibility rule. Despite its success as a rules-based system, the gold standard collapsed because World War I completely unraveled the global financial system and virtually bankrupted all of the European belligerents. Had the War not happened it could have lasted longer.

\subsection{The Interwar Gold Exchange Standard 1924 to 1936}

After World War I, Great Britain, France and other countries expressed a strong desire to restore the gold standard but high inflation and debt overhangs, many believed, would require major international cooperation and coordination to restore it.

Two important conferences in Brussels 1920 and Genoa 1922 set the stage for the restoration of the gold standard. Because of a predicted gold shortage (the real price of gold had been vastly deflated by the global wartime inflation) it was to be a gold exchange standard under which members would hold both foreign exchange (dollars and pounds sterling) and gold as international reserves. Great Britain and the US were to be the center countries of the new international monetary system and they were to hold their international reserves in gold valued at the prewar parities.

Extensive international cooperation was required to stabilize the central European countries which had run hyperinflations. The stabilization packages were imposed by 
the League of Nations and private sector lenders such as JP Morgan in return for the loans required to build up the reserves needed to restore convertibility which involved massive disinflation and budget balance. To facilitate Great Britain's return to gold in 1925, the New York Fed established a \$200 million line of credit for the Bank of England in New York (Bordo et al. 2015 chapter two). The Fed also kept its policy looser than would otherwise have been the case (Friedman 1953).

The interwar gold standard was based on the convertibility rule as was its prewar ancestor, but the rule was more fragile and less credible. One key difference between the gold exchange standard and the classical gold standard was that few countries were perceived to be willing to maintain external balance at the expense of domestic policy goals. ${ }^{2}$ Central banks began to focus more on stabilizing the business cycle in support of expansionary economic policy targets for employment and growth .In addition, many of the post WWI parities were misaligned, reflecting mis-calculation of equilibrium exchange rates and political pressures. Sterling was pegged to gold at an overvalued (pre-war) parity in April 1925 while France went back in 1926 after an $80 \%$ devaluation, at a greatly undervalued parity. This meant that the adjustment mechanism of the gold standard was destined to malfunction (Meltzer 2003). The Bank of England had to continually tighten monetary policy to protect its gold reserves in the face of persistent balance of payments deficits, which continually deflated the British economy (Keynes 1943). At the same time, France ran persistent balance of payments surpluses, which should have led to an expansion in the money supply and inflation but instead were continuously sterilized. This meant that France was absorbing a larger and larger amount of the world's gold reserves (Irwin 2013). The US kept sterilizing its surpluses, joining France in sucking gold from the rest of the world. In addition to the maldistribution of gold, the system was further weakened by failing confidence in sterling as a reserve currency. Declining gold reserves at the Bank of England and Federal Reserve sterilization policies prompted countries to shift their foreign exchange reserves from sterling to dollars (Eichengreen et al. 2016).

Against this background of flawed rules, considerable central bank cooperation was required just to prop up the system. Much of the cooperation was personal; between Montagu Norman, Governor of the Bank of England, Benjamin Strong, Governor of the Federal Reserve Bank of New York, Hjalmar Schacht, President of the Reichsbank and Emile Moreau, President of the Banque de France (Clarke 1967; Ahamed 2009; James 2016). Norman and Strong worked tirelessly to get the gold standard working. Once underway, the perennial problem of sterling's weakness came to the fore. It was aggravated by the Banque de France's pro gold policy of converting sterling bills into gold. In July 1927 Strong organized a clandestine meeting between the four governors at the Under Secretary of the Treasury Ogden Mills' house on Long Island. At this meeting one of the classic monetary policy co-ordinations of all time was worked out to protect sterling. The New York Fed agreed to cut its discount rate and to conduct expansionary open market operations while the Banque de France (and the Reichsbank) agreed to shift their gold purchases from London to New York. Sterling was saved for

\footnotetext{
${ }^{2}$ Because of the extension of the franchise in most countries, the growth of organized labor and the fresh responsibilities of governments for the economic and social welfare of their populations after the terrible experience of war, more emphasis was placed on domestic output, employment and price stability (Eichengreen 1992)
} 
another day but the meeting led to serious criticism of Strong's actions by Adolph Miller, a Governor of the Federal Reserve Board, who blamed his actions for fueling the Wall Street boom which burst in October 1929. Board. Moreover, Strong's actions bailing out Britain on two occasions may have encouraged moral hazard by discouraging the British from learning to adjust (Meltzer 2003).

After Strong's death in 1928 and Schacht's departure from the Reichsbank, Norman pushed hard to institutionalize monetary policy cooperation, which came to fruition with the creation of the Bank for International Settlement (BIS) in Basel in 1930.

The initial operational purpose for the BIS was to manage German reparations after the Young Plan, but its more fundamental function was to provide a forum to promote central bank cooperation. It was also supposed to be a venue for central bank cooperation by sharing information and providing a confidential forum for central bankers to meet on a regular basis as well as providing services for central banks (e.g. gold swaps, deposits, lines of credit) (Toniolo and Clement 2005, Borio and Toniolo 2005). But its early attempts at cooperation were not successful (James 2016). The BIS was involved in two failed attempts in spring/summer of 1931 to rescue the Austrian schilling and the German mark. Its resources were too small and the rescues did not have the political backing of France.

The architecture of the interwar gold standard emphasized the importance of central banks for the exercise of monetary policy. The delegates at the Genoa International Economic Conference in 1922 explicitly stated that central bank cooperation was a vital aspect of a prospective new gold standard and that this should be institutionalized in a convention or 'entente' (Schenk and Straumann 2016; James 2016). Montagu Norman promoted a network of central banks modeled on the Bank of England that could cooperate to deliver 'orthodox' policies aimed at monetary and exchange rate stability. His vision was supported by the Financial Committee of the League of Nations, which sent missions to a range of central European states in the mid-1920s as part of creating a coordinated international monetary system. With the increased prominence of central banks and the establishment of the Bank for International Settlements, the interwar gold standard (while itself a failure of cooperation and coordination) set the foundations for central bank cooperation for the next century.

The gold exchange standard collapsed amid the shocks of the Great Depression.

Two major attempts at monetary policy coordination were undertaken in the 1930s as the gold exchange standard collapsed, one a disaster and one quite successful. The League of Nations sponsored the London Monetary and Economic Conference in June 1933 to try to stabilize exchange rates and achieve concessions on trade restrictions. The London conference failed, torpedoed by President Franklin Delano Roosevelt's unwillingness to be constrained by the gold standard.

Three years later, the timing was more propitious for successful cooperation under the Tripartite Agreement of 1936 between the US, UK and France as the French position had become untenable when the dollar and sterling depreciated against gold. France needed a coordinated devaluation to prevent a free fall in the franc, and the US and UK also had an interest in an orderly depreciation of the franc. With this coincidence of interest, it was possible to agree to a common strategy not to manipulate exchange rates for national advantage. Each country's Exchange Stabilization Fund engaged in daily coordinated exchange market intervention to produce an orderly devaluation of the French franc. It ended at the outbreak of WWII (Bordo et al. 2015 chapter 3.) 
Monetary policy cooperation and coordination certainly contributed to the interwar gold exchange standard's problems by propping up a flawed system and possibly even helping fuel the 1920s asset price boom. Central bankers were later blamed for the Great Depression and had their powers and independence stripped, with important consequences for the postwar period. Unlike the prewar gold standard, although the gold exchange standard was rules based, the circumstances and implementation of the rules were flawed from the beginning. Central bank monetary policy cooperation and coordination did not function well in this environment.

\subsection{The Bretton Woods International Monetary System 1944 to 1973}

A key goal of the post-war period was to create a framework for cooperation and coordination underpinned by credible rules to ensure a lasting and prosperous peace (Giovannini 1993). For monetary policy, the rules were to maintain pegged exchange rates within narrow bands $( \pm 1 \%)$ supported by controls on short term capital flows and access to short term credit (from the International Monetary Fund) to cover temporary balance of payments imbalances. Unlike the interwar system, member countries could adjust their parities in the event of a 'fundamental disequilibrium' (which was never defined). The gold convertibility rule was preserved through fixing the gold price of the US dollar at $\$ 35 / \mathrm{oz}$. The other members pegged their currencies to the dollar.

It took until December 1958 for the Bretton Woods system to get underway once the Western European countries achieved current account convertibility. In the immediate aftermath of the war other systems of coordination were formed to allow multilateral trade without full convertibility: the European Payments Union (EPU) and the Sterling Area were the two most prominent examples (Bordo and Schenk 2016).

Once the Bretton Woods system was set up it began to face stresses that required increased cooperation. However as long as the center country, the U.S. followed the basic convertibility rule and maintained low inflation the system held up.

In the 1960s it became increasingly difficult to contain capital movements once inconsistencies between domestic priorities and the peg opened up. Offshore markets in London tested the credibility of adherence to the exchange rate rule, and there were repeated parity adjustments that undermined the system as a whole. The pegged rate rule was operated too inflexibly, so instead of small and frequent adjustments, there were repeated speculative rushes on the DM, Franc and sterling, in particular, through the 1960s. By the end of the 1960s these attacks had spread to the dollar at the heart of the system and the gold convertibility rule was effectively abandoned in March 1968.

The Bretton Woods system is an example of an elaborate effort at institutionalized coordination that failed because of fundamental flaws in the rules underpinning the system (Schenk 2016). Instead, a set of cooperative initiatives were deployed to prop the system up on an ad hoc basis until the convertibility and exchange rate rules finally gave way in 1973. This cooperation among leading industrial economies (promoted in part by Cold War ideology) allowed the global economy to reap the benefits of freer trade and technological innovation during the first 30 years after the end of the Second World War so that the Bretton Woods era was characterized by low inflation and rapid growth (Bordo 1993).

The most serious vulnerability in the Bretton Woods rules arose from the use of the dollar as an international reserve currency, and therefore reliance on US monetary 
policy. After European states declared current account convertibility at the end of 1958, Robert Triffin (1960) warned that once outstanding dollar reserves held by the rest of the world surpassed the US monetary gold stock that this would increase the possibility of a run on the dollar and a collapse of the system (Bordo and McCauley 2019). Thinking in terms of the interwar experience, Triffin worried that US monetary authorities would tighten policy leading to a world depression. For him the solution was the creation of an alternative reserve asset subject to coordinated management, like Keynes's (1943) proposed bancor.

Closely related to the Triffin paradox was the critique that the US gained an exorbitant privilege from the dollar's position in the system. Since the dollar was an international reserve currency, the US did not have to adjust to balance of payments deficits, could promote outward direct investment (acquiring foreign assets) and the US government could borrow at lower rates than otherwise because of the global appetite for dollar denominated assets. The French in particular resented this and periodically pressed for the world to return to the classical gold standard (with disruptive effects (Rueff 1961). Recent efforts to measure the 'privilege' accorded to the USA find it to be very small (McCauley 2015). Meanwhile, West Germans viewed the US deficits as inflationary, which ran counter to Germany's strong preference for stable prices and inhibited the Bundesbank from adjusting the DM or reducing persistent German balance of payments surpluses (Emminger 1967).

Nevertheless, the dollar persisted at the core of the system because of its desirable properties as a vehicle currency and the unrivalled breadth and depth of US financial markets. At the time, Despres et al. (1966) argued that the US acted as a financial intermediary borrowing short term deposits and lending long term foreign investment. In this view, as long as the Fed followed credible monetary policy the dollar standard could persist.

As threats to the Bretton Woods system mounted through the 1960s, enormous energy was put into efforts to renew the framework for international policy coordination. The General Arrangements to Borrow (GAB) in 1961 created a line of credit at the IMF sufficient to satisfy a speculative attack on a large country like the U.S. Its lasting importance is perhaps less through its direct effect and more from the creation of a new tier of leadership in the global system. The Group of 10 countries involved in the GAB became an alternative to the IMF Executive Board as leaders of reform and as a forum for cooperation, challenging the broader constituency of the IMF and the interests of emerging market economies. ${ }^{3}$ The G10 as a coordinating forum was further reinforced since the G10 central bank governors formed the governing board of the Bank for International Settlements.

In addition to these ambitious efforts at renewed coordination through the IMF, was the increased intensity of central bank cooperation through the auspices of the Bank for International Settlements. The monthly meetings of G10 central bank governors, supported by a technocratic secretariat and a set of topic-based expert standing committees (Goodhart 2011; Toniolo and Clement 2005) provided an opportunity for 'soft' cooperation through a sharing of ideas, policies and instruments as well as flexible, simple and effective responses such as coordinated lines of credit and swaps.

\footnotetext{
${ }^{3}$ G10 were Canada, UK, USA, Italy, France, Belgium, Netherlands, Japan, Sweden, and West Germany. Switzerland also participated in multilateral activities through the BIS. Luxembourg also joined for the Basel Committee.
} 
The meetings were private and secret, with no formal minutes and this promoted a frank exchange of views. The monthly meetings of G10 central bank governors and their staffs in Basel did not attract political attention or require parliamentary oversight in the way that IMF meetings and edicts did. The BIS, therefore, became a preferred venue for cooperation for countries such as the UK, which struggled to maintain the sterling exchange rate through the 1960s until it floated in June 1972 (Schenk 2010; Schenk 2016).

There were three main cooperative efforts among central banks to support the gold and exchange rate rules of the Bretton Woods system; the Gold Pool, multilateral Group Arrangements and bilateral Fed swaps.

The Gold Pool began as an intergovernmental initiative from the US Treasury Secretary in September 1961 to keep the market gold price at the official price (Bordo et al. 2019). It was thrust upon the G10 central bank governors in November 1961; only the Bundesbank was an enthusiastic supporter from the outset (Toniolo and Clement 2005 pp. 376-77). Each central bank pledged a set amount for gold sales to the pool and the US Fed matched the amounts of the other members to a total of $\$ 270$ million. On the other side, the Bank of England intervened to buy gold when this would not raise the gold price. Part of the proceeds from these operations ( $\$ 30$ million) was kept to fund sales, thus saving the formal gold pool for times when there was a sustained upward pressure on the gold price, which started from 1965. ${ }^{4}$ The Pool operated reasonably well until after the devaluation of sterling by $14.3 \%$ in November 1967. This prompted a fatal loss of confidence in the gold value of the dollar and the market rate of gold was finally allowed to rise after a run in March 1968, although central banks and the IMF agreed to continue to trade at the official rate of $\$ 35 / \mathrm{oz}$. At this point, it became clear that the resources of central banks could not 'buck' the market for any length of time and the Gold Pool was abandoned.

A second (and less well known) support was the arrangement of coordinated lines of credit among the G10 central bank governors at the BIS starting in 1960 (Schenk 2010; Toniolo and Clement 2005). A spike in the London gold price to $\$ 40.00$ in October 1960 on fears that John F Kennedy would follow an inflationary policy if elected led to a flurry of attempts at cooperation (including gold swaps) between the ESF and a range of European central banks, a $\$ 1$ billion credit line of gold from the BIS and finally revaluation of the DM and Dutch guilder in March 1961.

In this context of dollar fragility, the British convinced the G10 that supporting sterling was a vital bulwark for the continuation of the Bretton Woods system and thereby garnered multilateral support. The Italian lira received significant support but sterling was the main beneficiary, repeatedly arranging emergency short term lines of credit: \$904 million in 1961, \$250 million in March 1963, \$1 billion in September 1964, \$3 billion in November 1964.

From 1965 the Bank of England began to negotiate a longer term solution to the retirement of sterling as a reserve asset, culminating in the First Group Arrangement between the G10 central banks and the BIS in 1966, for up to $\$ 1$ billion in support to be activated by a specific fall in global sterling reserves (Schenk 2010).

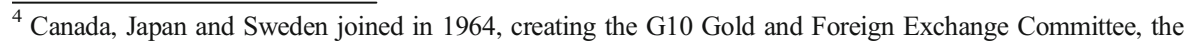
precursor to the current Markets Committee.
} 
In the midst of a run on the dollar and the collapse of the Gold Pool in March 1968, the Bank of England tried unsuccessfully to get a new package of $\$ 5$ billion in credit. Instead central banks pledged $\$ 1.175$ billion, almost half from extending the Fed's UK swap facility from $\$ 1.5$ billion to $\$ 2$ billion. Soon after, the BIS began to plan a Second Group Arrangement to retire sterling, supported by a $\$ 2$ billion line of credit (equiv. $\$ 38$ b today). This time, the UK was forced to negotiate bilateral agreements with each individual country that held substantial sterling reserves (34 in all) to limit the diversification of their reserves. ${ }^{5}$ This Second Group Arrangement was finally concluded in September 1968, popularly known as the Basel Agreement. It was renewed several times (despite the depreciation of the dollar in 1971 and the float of sterling in 1972).

A third defense for the dollar was the Federal Reserve's series of bilateral swap lines between the US and major currencies begun in 1962. The swaps were covered shortterm loan facilities between the Fed and other central banks, usually for 3 months, and served two purposes. Countries outside the US drew dollars to intervene in foreign exchange markets to support their currencies (the Bank of England drew $\$ 8.65 \mathrm{~b}$ from 1962 to 71. On the other side, the Fed drew on the swaps to support the dollar price of gold. These swaps provided a short-term exchange value guarantee and thereby discouraged central banks from converting their unwanted or 'excess' dollars to gold. ${ }^{6}$ The Fed drew \$11.6b in foreign currencies from 1962 to 71 (Bordo et al. 2015). These swap lines were sometimes retired with foreign exchange or Roosa bonds (US Treasury securities denominated in foreign currencies) (Bordo et al. 2015 Ch. 4). The swap network expanded from less than a billion dollars in 1962 when the first swap was made with France, to close to $\$ 12$ billion by August 1971 and $\$ 20$ b by in mid-1974 by which time the network included 14 central banks (including the BIS). (See Fig. 1).

These tools and rescue packages all worked in the short-run to head off the 'crise du jour' but the system was no longer consistent with US domestic policy goals. By the spring of 1971 the French and British threatened to convert their outstanding dollar holdings into gold (Garber 1993; Bordo 1993) and in August 1971 President Nixon closed the US gold window on the advice of his Treasury Secretary Connolly. The Bretton Woods system did not collapse into deflation as Triffin prophesized; rather the problem was inflation. The US followed the key gold standard rule of keeping inflation low until 1965, but from then on the Fed followed expansionary monetary policy to help finance the Vietnam War and LBJ's Great Society. It thus broke the basic rule of the Bretton Woods System and the Europeans became increasingly critical of US inflation (Bordo 1993).

Like the interwar system, Bretton Woods was a rules-based system but the rules were both analytically flawed and incompatible with the political economy environment of the time. In each case the exchange rate rule was formally set (and in Bretton Woods there was an elaborate institutional framework to promote coordination) but there was no underpinning domestic policy rule to support the system. Policy makers at the time had an incomplete understanding of the role and effect of monetary policy and

\footnotetext{
${ }^{5}$ In 1968, 23 countries held over half of their reserves in sterling.

${ }^{6}$ Swaps were also used to stabilize the Eurodollar market, a market set up in London primarily to circumvent U.S. financial regulations such as regulation Q, the ceiling rate on time deposits. Swaps between the Fed and the BIS were used on occasion in the 1960 s to smooth spikes in the spreads between offshore and US interbank rates. A key reason for their use was to aid the Fed in its monetary policy objectives. See McCauley and Schenk (2020)
} 


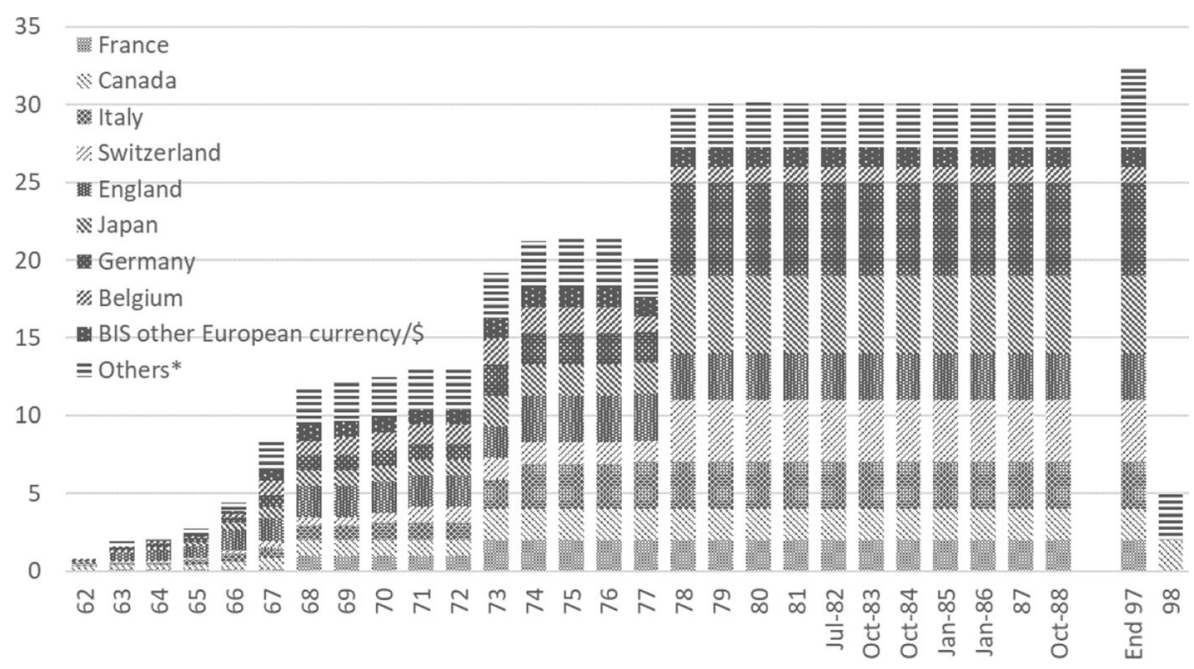

Fig. 1 US Swap Lines 1962-1998 (billions of US Dollars at end year). Others: Denmark, Norway, Austria, Sweden, BIS SFr/\$, Mexico, Netherlands, Belgium Source: Data from McCauley and Schenk (2020). "Central bank swaps then and now: swaps and dollar liquidity in the 1960s" BIS Working Paper 851 paper, Graph 2

they prioritized the pursuit of full employment over price stability (to varying degrees). To top this off, the US as center country broke the key rule of the system by running an inflationary policy. That the Bretton Woods system lasted as long as it did was due in a significant way to effective central bank cooperation encouraged by a deep fear of floating exchange rates and the impact on the global economy of a collapse of the exchange rate rules. This cooperation transcended the collapse of the system that it was supposed to defend.

\subsection{The Managed Float}

After President Richard Nixon closed the gold window in August 1971 there was still considerable interest among major countries in restoring the par value system. The Smithsonian Agreement in December 1971 rebuilt the pegged exchange rate system with wider bands, but the credibility of the system quickly evaporated in the face of continued U.S. inflation which precipitated repeated runs on the dollar until most countries had abandoned their dollar pegs by the spring of 1973 .

\subsubsection{The $1970 \mathrm{~s}$}

The international monetary system switched to a managed floating regime in 1973. Milton Friedman (1953) argued that floating rates had the advantages of insulating the domestic economy from external monetary shocks and that they gave monetary authorities the independence of conducting monetary policy to satisfy domestic goals without imposing capital controls. According to Friedman, independence from the constraint of pegged exchange rates required monetary authorities to follow stable rules based monetary policies. Otherwise monetary instability, in addition to producing instability in prices and real income, would also lead to instability in the nominal exchange rate. 
It took close to two decades for the Federal Reserve and other central banks (with the principal exceptions of the Bundesbank and the Swiss National bank) to learn this lesson. The 1970s was a decade of monetary instability manifest in high and variable inflation. This was reflected in exchange rate volatility.

Monetary authorities engaged in extensive intervention to stem the perceived volatility of exchange rates. The Fed and other central banks believed that foreign exchange markets were inherently unstable and that exchange market intervention was required to keep exchange rates close to their fundamentals and to reduce unexplained volatility (Bordo et al. 2015 chapter five). It was not until the next decade that the Fed and other central banks learned that stable domestic monetary policy geared to low inflation would reduce instability in nominal exchange rates.

The Fed's central bank swap system also continued, and, it increasingly drew on the swap system to support the U.S. monetary authorities intervention to stabilize the dollar. By 1978 total facilities totaled $\$ 29.4$ b, although at its highest point (in 1978) outstanding Fed swap obligations amounted to only $\$ 5.5 \mathrm{~b}$. The publicized ceilings had a largely representational purpose to demonstrate the commitment of the partners (Bordo et al. 2015).

Against the background of rising inflation and with the dollar depreciating against the DM and yen and other currencies, the Federal Reserve engaged in frequent and massive sterilized exchange market intervention. Many of the sales of DM and Yen were financed by borrowing via swap lines with the Bundesbank and other central banks until 1980. Some of the Fed interventions were coordinated with similar operations by the Bank of Japan, Bundesbank and other central banks.

After December 1975 the Fed cooperated closely with other central banks, keeping them informed daily of their actions, although all of the operations in this period were covert. Empirical evidence suggests that much of the intervention had very small and possibly very temporary effects in reversing exchange rate movements. Bordo et al. 2015 (p. 236) concluded that for the 1974 to 1977 period "only 49 per cent of the active interventions to support the dollar and only 64 per cent of the passive interventions to acquire German marks appear successful."

The situation worsened in the next three years. In 1978 the dollar went into a free fall reflecting the Fed's lack of success in arresting inflation. On November 11,978, the Carter administration (along with the Fed) announced a massive dollar defense package consisting of a 1 percentage point increase in the discount rate to $91 / 2$ per cent, a $\$ 30 \mathrm{~b}$ increase in foreign resources and closer cooperation with Germany, Japan and Switzerland. The foreign currency package included a $\$ 47.6 \mathrm{~b}$ increase in the Fed's swap lines with these countries. The Treasury also would issue up to $\$ 10$ billion in German mark and Swiss franc denominated securities, called Carter bonds (Bordo et al. 2015 page 243). Massive coordinated exchange market interventions with the Bundesbank and other central banks followed in the next two months. In reaction to these actions the dollar began appreciating against the mark.

But the evidence for the period September 1977 to October 51,979 suggests that "despite the changes in amounts, frequency, objectives and openness, US operations were no more effective than the earlier operations. As in the pre-1977 period, they demonstrated some tendency to moderate exchange rate movements" (Bordo et al. 2015 page 247). 
In reaction to the volatility in the dollar and the public's reaction to rising inflation and inflation expectations, President Carter appointed Paul Volcker as Chairman of the Federal Reserve Board in October 1979 with the mandate to end the inflation. The Volcker shock of October 51,979 when the Fed shifted to a tight monetarist type monetary (non-borrowed reserves) targeting strategy, raised the discount rate, imposed reserve requirements and allowed interest rates to rise dramatically, eventually broke the back of inflation and inflationary expectations and reversed the decline of the dollar. Similar policies were followed in other countries.

The 1970s was a low point for the IMF as the official hub of international monetary coordination. It was only in 1976 that the IMF finally recognised the legitimacy of flexible or floating exchange rates and from this time the IMF, seeking a role to replace the one it had lost, turned more resolutely to focus on the interests of developing economies rather than governance of the international monetary system. This effort also brought mixed success as the gap between rich and poor countries widened and many economies accumulated unsustainable amounts of debt, which erupted in the 1982 sovereign debt crisis.

Instead, the mid-1970s gave rise to the ' $\mathrm{G}$ '-summits, starting with the G6 at Rambouillet in 1975, adding Canada in 1976 and then Russia in 1998 to form the G8. These were annual meetings of political leaders supported by finance ministers' meetings and meetings of central bankers. For central banks, of course, the summits supplemented the regular monthly meetings among G10 central bank governors at Basel. The summits generally resulted in rather mundane and repetitive public statements committing the participants to ensuring stable markets, but they also provided an opportunity for sharing of ideas and approaches to global economic challenges informally.

Monetary cooperation via coordinated exchange market intervention (EMI) and other strategies did not work in the 1970s. This was because most central banks did not follow a rules based policy of keeping domestic inflation low, consistent with being on a floating exchange rate (Bordo et al. 2015).

\subsubsection{The $1980 \mathrm{~s}$}

The 1980s saw a return to a consensus in monetary theory and policy. Paul Volcker's success in stemming inflation in the US was applauded by central bankers and governments across the developed world. An examination of the minutes of the monthly meetings of the G10 central bank governors shows that in the 1970s they shared their common frustrations with their governments' inability to be consistent in their policy guidance and the ensuing lack of credibility of monetary policy. They wriggled under their lack of independence when orders came from ministries to reverse tight money to promote growth targets at the expense of higher inflation.

Through these regular meetings at the BIS the G10 central bank governors created an epistemic community with shared goals for inflation but also a general commitment to avoid destabilising short term exchange rate changes. As the operational arm for coordination, this forum was important for sharing information, debate and forming opinion even though they lacked policy independence. This observation goes beyond Eichengreen (2013) identification of the Basel Committee on Banking Supervision as an epistemic community, to include the formative development of common approaches to monetary policy. 
Volcker's policy shift set the stage for a new domestic based rule for monetary policy that was eventually adopted by other advanced country central banks. The ability to follow a monetary rule was dramatically reinforced by innovations in smaller countries. New Zealand's experiment with central bank independence and transparent inflation targeting set the model for the transformation of the credibility of monetary rules, just as economic theory and understanding of monetary policy was enhanced by the identification of the Taylor Rule. By the end of the 1980s, therefore, we had returned to a rule based system founded on domestic monetary policy actions by independent central banks acting in their own countries' interests, which seemed to generate a lasting period of moderate inflation. But the lingering ambitions for more elaborate coordination had much less success.

While central bankers moved closer to a common understanding on monetary policy, governments and Treasury bureaucrats continued to seek exchange rate stability or at least the 'orderly exchange markets' described as the agreed goal in the revised IMF statutes. Exchange rate volatility continued as central banks learned to adopt and operate the new set of domestic monetary rules, and the 1980s witnessed a series of grand gesture summitry to coordinate exchange rate and fiscal policy that produced mixed results.

The Volcker shock and three years of tight monetary policy led to a decline in inflation from a peak of $15 \%$ in 1979 to $3 \%$ by the mid-1980s. This led to a marked appreciation in the dollar to advanced countries by $55 \%$ on a trade weighted basis. By 1985 Germany and other countries were complaining about the imbalances and the Bundesbank had been intervening to offset the depreciating mark. More important, the strong dollar was harming the exports of US manufactured goods and this led to threats in the Congress to raise tariffs. The incoming Secretary of the Treasury James Baker was a much bigger fan of macroeconomic policy coordination and of EMI than his predecessor Donald Regan (under whose watch there was only limited EMI). So at the G7 Finance Ministers Summit meeting at the Plaza hotel in New York City on September 221,985 ministers agreed that coordinated EMI would be used to depreciate the dollar. They also agreed that the US would follow expansionary monetary policy and Japan would do the opposite.

Immediately upon the announcement the dollar declined. However, it had been falling since February 1985 and the increase before the meeting was only a temporary blip. Massive coordinated intervention by the Fed, Bundesbank and Bank of Japan lasted two weeks but the evidence that it was successful is limited Feldstein (1986); Humpage (1988) argued that monetary policy had turned looser well before the Plaza and that this more likely explained the turnaround in the dollar. Bordo et al. 2015 (page 304) found that the EMI did not have much effect on the exchange rate. On the other hand, Dominguez and Frankel (1993) found that coordinated EMI did have significant effects and Frankel (2016) argued that the Plaza was a success. However, the part of the agreement that urged Japan to follow tighter monetary policy than consistent with macro fundamentals led the Bank of Japan to keep rates higher than would be the case had it followed a Taylor rule in 1986 (International Monetary Fund 2011, Taylor 2016).

The dollar declined through 1986 leading to concerns that it had fallen too far. Members at the G7 meeting at the Louvre February 221,987 agreed to coordinate policies to stabilize the dollar. This meant coordinated EMI in the opposite direction than at the Plaza, and that Japan would follow more expansionary monetary and fiscal 
policy while the US and Germany and the others would keep their macro policies constant. As with the Plaza Agreement, there is strong evidence that the EMI had little effect (Bordo et al. 2015) but there were longer lasting effects on the Japanese economy that were devastating. After the Louvre Accord policy rates deviated in a negative way from a rules based policy and many argue that this expansionary monetary policy triggered the asset price boom bust leading to a serious banking crisis, and over a decade of stagnation.

\subsubsection{The Great Moderation 1985 to 2006}

By the late 1980s most advanced countries had low inflation, had adopted central bank independence, and were following rules based monetary policy. This led to a 20-year period of stable and low inflation, and stable and rapid real growth called the Great Moderation. Most of the disturbances in the global economy arose in emerging economies rather than industrialised countries at the core of the global trade and financial system.

Beginning in the late 1980s the Federal Reserve began to turn away from the use of exchange market intervention as a significant policy tool. An extensive debate at the FOMC and in the academy argued that sterilized EMI and credible monetary policy were conflicting goals. By 1995 Chairman Greenspan agreed and the US only undertook such actions on three occasions since. Also in this period economists argued, based on game theory and multi country econometric models, that central banks that pursued credible rules based monetary policy minimized the spillovers that were believed to have necessitated coordinated policies (Taylor 1985). As it turned out, in this period there were fewer occasions when there was a call for monetary policy coordination other than the mundane statements at G7 summits. Instead, the main focus of cooperation/coordination returned to crisis management in a series of emerging market crises.

\section{Emerging Market Crises}

While industrial countries mainly adopted floating or managed floating exchange rates, many emerging market economies with underdeveloped financial systems, and thin and shallow domestic foreign exchange markets opted for adjustable pegged exchange rates. Through the mid-1980s many of these economies grew quickly through export oriented industrialization, particularly in East Asia. They were encouraged by the IMF and World Bank to liberalize their capital markets but their institutions were not strong and this contributed to a rash of financial and currency crises in the 1990s as the dollar appreciated. $^{7}$

These episodes were viewed as posing systemic threats via contagion to the advanced countries and prompted calls for international cooperation, with central banks serving as lenders of last resort to supplement the resources of the IMF. The pattern of support packages echoed several aspects of the Basel Agreements of the 1960s and

\footnotetext{
${ }^{7}$ In the 1990s many emerging market countries were advised to adopt firm pegs or currency boards to import credible non-inflationary monetary policies.
} 
1970s; the reluctance of debtors in crisis to submit to the IMF as a first line of defense, the insistence of creditors on an IMF seal of approval before offering coordinated bilateral support, the preference of central banks and governments to provide only contingent lines of credit that they hoped would not be drawn. But they differed significantly because the operations were bail-outs rather than rescues (in the lender of last resort sense) (Bordo and Schwartz 1999, 2000) and this heightened the moral hazard.

In each case (Mexico, Thailand, Indonesia, South Korea, Brazil, Argentina, Russia) the crisis arose from overvalued currencies pegged to the US dollar, which were toppled by a sudden reversal of capital flows that prompted uncontrolled devaluation and a financial crisis. Weak financial sectors, heavy foreign currency denominated borrowing, government guarantees and exuberant investors contributed to the fragility of the system (Bordo and Meissner 2016). In each case the debtor country initially sought to by-pass the conditionality of the IMF and activate swaps or bilateral support (Boughton 2012). But, in line with the final coordinated support offered by the G10 to the UK in the 1970s, creditor countries insisted on an IMF 'seal of approval' through a contingent (smaller) stand-by agreement with a letter of intent. The IMF insisted on devaluation, restructuring financial markets and fiscal retrenchment, with mixed success. International policy coordination was thus operated through the IMF Executive Board and then central banks and finance ministers supplemented this credit, often in larger amounts. The difference from the 1960s and 1970s was that the funds were used to bail out creditors rather than as a resource for central banks to gain a breathing space. The coordinated operations therefore created moral hazard that was only partially offset by the IMF-induced restructuring programs (more successful in some countries than others).

The coordinated response to the emerging market financial crises was not a full success. Although the crises were eventually stemmed and growth returned under more flexible exchange rates, they left a legacy of institutional problems that exposed the weaknesses of these regimes a decade later. The bail-outs did not remove the incentive of countries to accumulate substantial precautionary reserves through persistent surpluses. The fragility of the global system was increased by many countries aiming to run persistent balance of payments surpluses during the 2000s as insurance against a future sudden stop and to avoid the necessity of submitting again to the disciplines of a future rescue package.

While the currency crises of the 1990s pushed most emerging market economies to greater flexibility by 2000, the People's Republic of China became an increasingly important non-conformist. The RMB exchange rate was not devalued in the wake of depreciations elsewhere in Asia and this helped to support export recovery in the region as Chinese economic growth accelerated in the run-up to WTO accession in 2001. From claims that the RMB was overvalued in the early 1990s, critics soon pointed to China's huge surpluses as proof that the RMB was undervalued. Capital controls and consistently high growth allowed China to resist calls to appreciate its currency, but the increasingly large and persistent current account surpluses, most of which was unsterilized, came at some cost to price stability, particularly in volatile real estate and other asset markets. At the same time, China's role in the governance of the global monetary system became more and more distant from 
China's importance in the global economy. In 2005 the RMB was appreciated slightly and a more flexible regime was adopted to allow an orderly appreciation, although the results were at first somewhat disappointing. China has had a challenging history with the IMF, mainly focused around the historically small quota (and therefore small voting rights), their iconoclastic international monetary policy and continued exchange controls (Schenk 2015).

Thus the coordinated rescues during the emerging market crises of the 1990s were quite far removed from rules based policy. First the rescues were bailouts to countries facing insolvency and not to countries facing a temporary liquidity shortfall, hence violating a key Bagehotian principle and engendering moral hazard for future crises. Second, these countries did not follow rule like domestic monetary policies because they had not developed sufficiently in the sense of following the rule of law and having deep and liquid financial markets etc. However, some of these countries in recent years have adopted rule like policies e.g. Mexico and South Korea, but not all (Bordo and Siklos 2019).

\section{The Global Financial Crisis 2007-2008}

The default on a significant fraction of subprime mortgages after the collapse of house prices in 2007 in the U.S. produced spillover effects around the world-via.

the securitized mortgage derivatives into which these mortgages were bundled - to the balance sheets of investment banks, hedge funds, and conduits (which are bank owned but off- their balance sheets) which intermediate between mortgage and other asset- backed commercial paper and long-term securities. The uncertainty about the value of the securities collateralized by these mortgages spread uncertainty through the financial system. All of this led to the freezing up of the interbank lending market in August 2007.

In an attempt to allay what it perceived as a liquidity crisis, the Fed then extended and expanded its discount window facilities and cut the federal funds rate by 300 basis points. A principal innovation was the Term Auction Facility (TAF) which allowed banks to bid anonymously for funds from the Fed. It was designed to encourage banks to go to the discount window by avoiding the "stigma problem" which had been so important in the 1930s.

The financial crisis led to severe pressures on dollar funding in the global financial system. This can be seen in Fig. 2 in a spike in the spread between the borrowing rate of overseas and U.S. banks (the overseas-U.S. Libor spread). The Federal Reserve set up swap facilities with the ECB and the SNB in December 2007 to facilitate their creation of TAF-like auction facilities to provide dollar liquidity to their domestic banks.

Following the bankruptcy of Lehman Brothers on September 15, 2008 the swap lines were made available to the Bank of Canada, Bank of England and the Bank of Japan, and then to 4 more central banks (the central banks of Brazil, Mexico, Korea and Singapore). The swaps operated like a Bagehotian lender of last resort facility with a small penalty rate.

The Fed viewed the swaps as both aiding its domestic policy objectives by preventing capital outflows which would hamper its domestic policy objectives and as central bank cooperation (McCauley and Schenk 2020). 


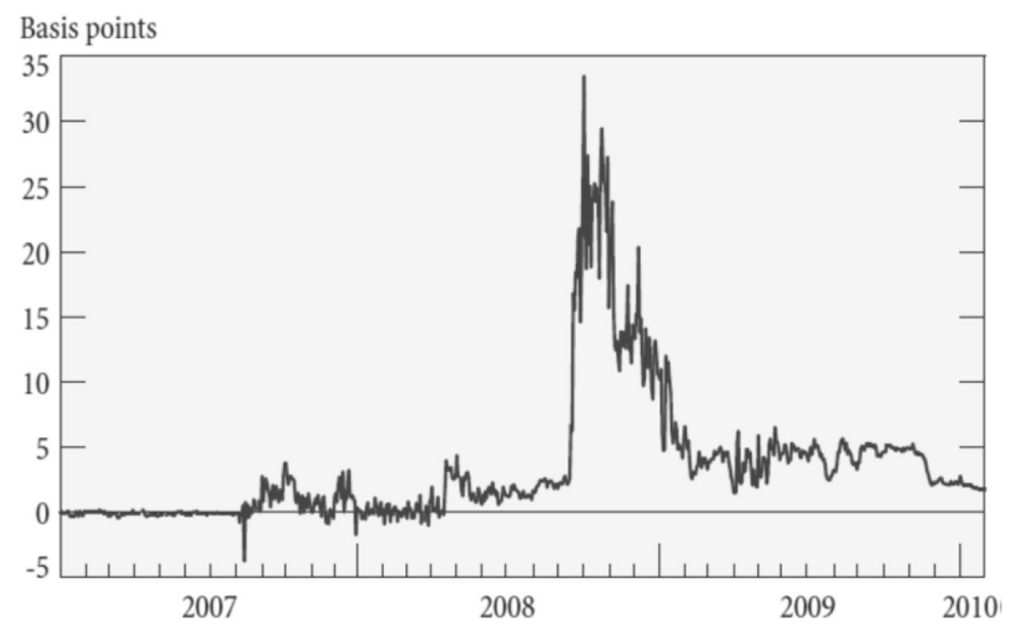

Fig. 2 Pressure on overseas dollar funding 2007-2008. Source: Chart 6 from Fleming, M. J., \& Klagge, N. (2010). The Federal Reserve's foreign exchange swap lines. Current Issues in Economics and Finance, 16(4)

The swaps increased from $\$ 20$ billion to a peak of $\$ 580$ billion in December 2008 (see Fig. 3). The swap program was highly successful in reducing the Libor OIS spread (McCauley and Schenk 2020; Bahaj and Reis 2019). ${ }^{8}$ (see Fig. 4).

The restored swap facilities echoed their use in the 1960s to alleviate pressure in the Eurodollar market. Indeed, swaps can be viewed as a form of International Lender of Last Resort and as a very successful form of central bank cooperation. Indeed cooperative policy may have averted a global panic ${ }^{9}$

In addition to the swaps, at the Summit in Washington DC in November 2008, leaders of the G20 committed themselves 'to stabilize financial markets and support economic growth', with particular emphasis on 'the importance of monetary support' as well as fiscal expansion. They also committed themselves anew to reforming the architecture of the international financial system and the governing board of the BIS was extended to allow nine other central banks to be members.

At the November 2008 G20 meeting new institutions were created to provide fora for cooperation. The IMF was tasked with monitoring spillover effects, publishing an annual report. The Financial Stability Board (2009) brought together central banks, finance ministries and supervisory agencies to encourage 'coherent implementation 'of good practice and implement agreed standards and codes, undertaking peer reviews of macro-prudential frameworks. The exchange of information, ideas and communication may bear some fruit in the long-term in creating consensus around a common or agreed framework of rules.

By the end of 2008, the financial crisis had ended but the real economy was still contracting and the federal funds rate and other central bank's policy rates had hit or were close to the zero lower bound. The Fed announced its policy of quantitative easing (QEI) in December 2008 - the unconventional policy of large scale open market purchases of long term Treasury securities and Agency mortgage backed securities.

\footnotetext{
${ }^{8}$ The swap lines were reopened during the Eurozone crisis in 2010 and were ended in 2013. Again like in the GFC, they were successful in reducing strains in the offshore dollar market.

${ }^{9}$ See Tooze (2018)
} 


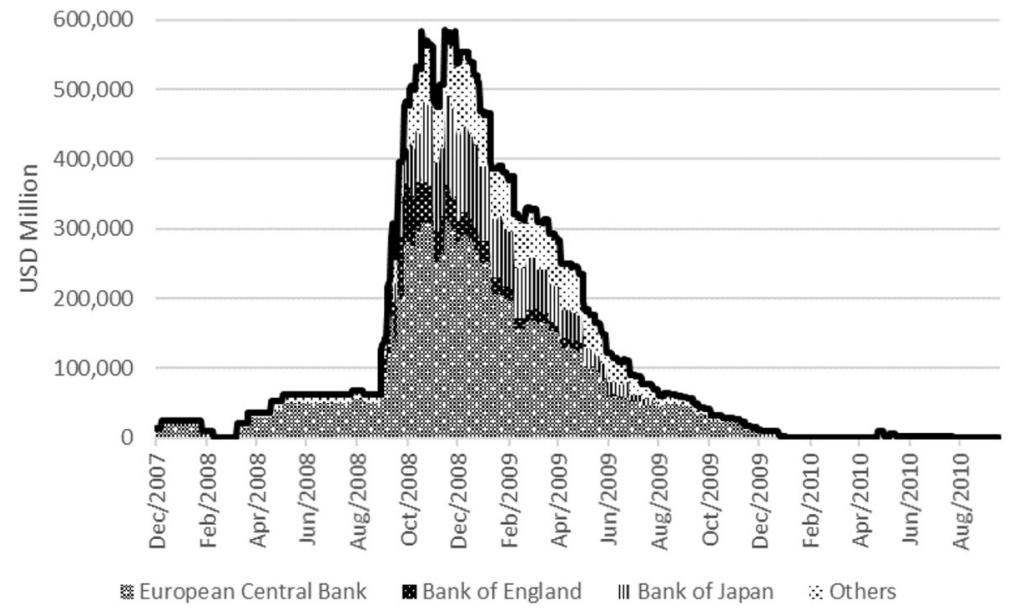

Fig. 3 US Dollar Liquidity Swaps by Central Bank 2008- Total Amount Outstanding- (USD million). *Others: Banco de Mexico, Bank of Korea, Danmarks Nationalbank, Norges Bank, Reserve Bank of Australia, Sveriges Riksbank, Swiss National Bank. Source: Federal Reserve Bank of New York, Own Calculations

In addition to the purchases the Fed began forward guidance to guide financial markets expectations. The Bank of England similarly engaged in quantitative easing from March 2009 and forward guidance from August 2013, related to a target unemployment rate of 7\%. The ECB followed in May 2009. Japan had a longer history of QE from March 2001-2006 and renewed its policy in October 2010. These initiatives were successful in arresting the Great Recession by June 2009 in the US, but the recovery that followed was anemic. Further, the spillover effects were controversial.

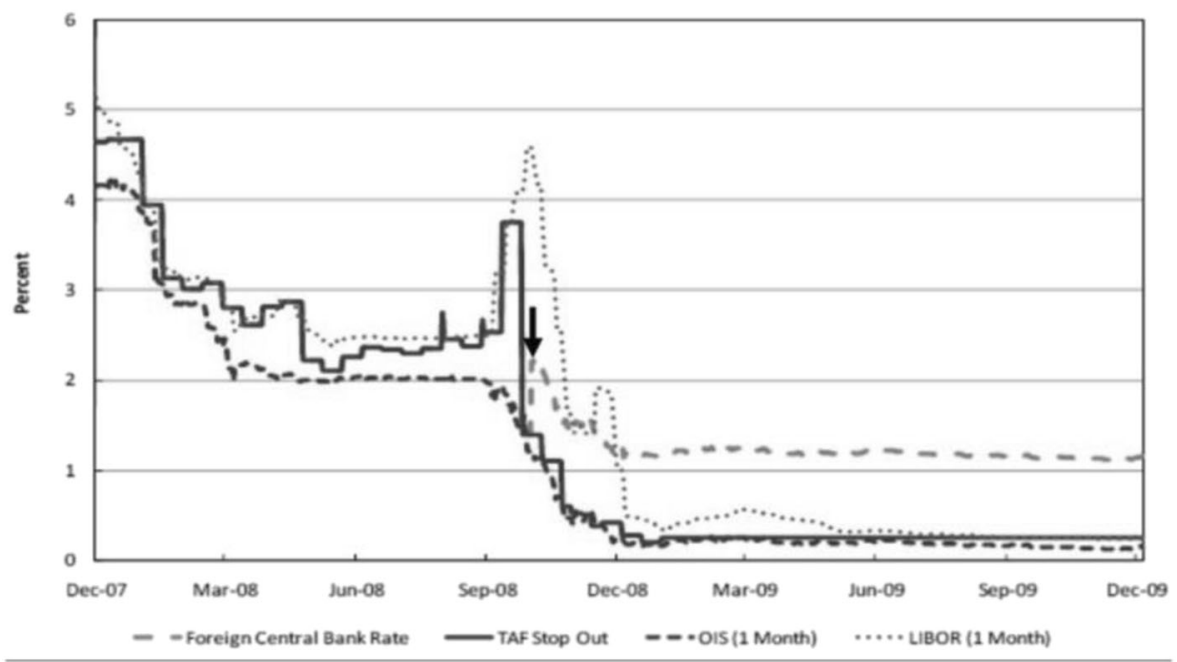

Fig. 4 Pressure on dollar funding eases 2008. Source: Graph 9 from McCauley and Schenk (2020). "Central bank swaps then and now: swaps and dollar liquidity in the 1960s" BIS Working Paper 851 paper 
QE policies deployed by advanced economies were particularly criticized for adverse effects on emerging market countries, primarily through capital flows and exchange rates. Investors surged into emerging markets, increasing asset prices and appreciating currencies. These spillover effects undermined export competitiveness, increased exchange risk on debt and threatened asset price bubbles. In May 2013, when Federal Reserve Chairman Ben Bernanke suggested that QE would be 'tapered', volatility in emerging market asset prices led to renewed calls for greater coordination. The specter of the inter-war crisis returned and (as in the interwar period) there were calls for greater monetary cooperation to avert a 'currency war' (described in Eichengreen 2013).

The extent and cause of spill-over effects has been disputed. Certainly, US monetary policy has global implications because of the importance of US capital markets and the role of the dollar. Spillover effects appear greatest when Fed announcements surprise the markets and there is evidence that these effects were greater after the global financial crisis than before it (Chen et al. 2014). The evidence seems to suggest that advanced economies should signal their policy to the market. Indeed Taylor (2016) argued that it is deviations from rules-based policies and towards discretion since 2002 (i.e. quantitative easing and forward guidance) that have led to the spillovers and that the solution is to return to the policies followed in the Great Moderation. This could involve a movement away from enlarged central bank balance sheets, quantitative easing and forward guidance-i.e. the normalization of policy rates and their use as a central bank's key policy tool. The case that greater monetary cooperation is a necessary solution to spillover effects is not proven.

\section{The Covid 19 Pandemic Crisis of 2020}

The Covid 19 pandemic became global in February and March 2020 when it spread from China to Europe and North America. When the authorities across the world mandated lockdowns on their economies it precipitated a global financial panic. The Federal Reserve and other central banks revisited their playbooks from the GFC a decade earlier and provided lender of last resort facilities to their domestic financial institutions. In the U.S. the Fed reinstituted many established as well as some novel liquidity provisions. As in the previous crisis there was an excess demand for dollar funding in other countries.

The Fed expanded its existing swap lines with five other central banks (Bank of Canada, Bank of England, Bank of Japan, ECB and SNB) on March 15. On March 18, for these countries, the spread on the swap line over OIS was cut from 50 to 25 basis points. As in the GFC, the haircut on the swap lines acted as a Bagehotian penalty rate. A new program with nine other central banks (Australia, Brazil, Mexico, Denmark, Norway, Sweden, Korea, New Zealand and Singapore) was created (See Fig. 5).

In addition to the swap lines, the Fed announced a new repo facility, the FIMA, a temporary repurchase facility for foreign and international monetary authorities. The new facility will allow approved holders to temporarily exchange their U.S. Treasury securities with the Fed for U.S. dollars. These can then be made available to their financial institutions. 


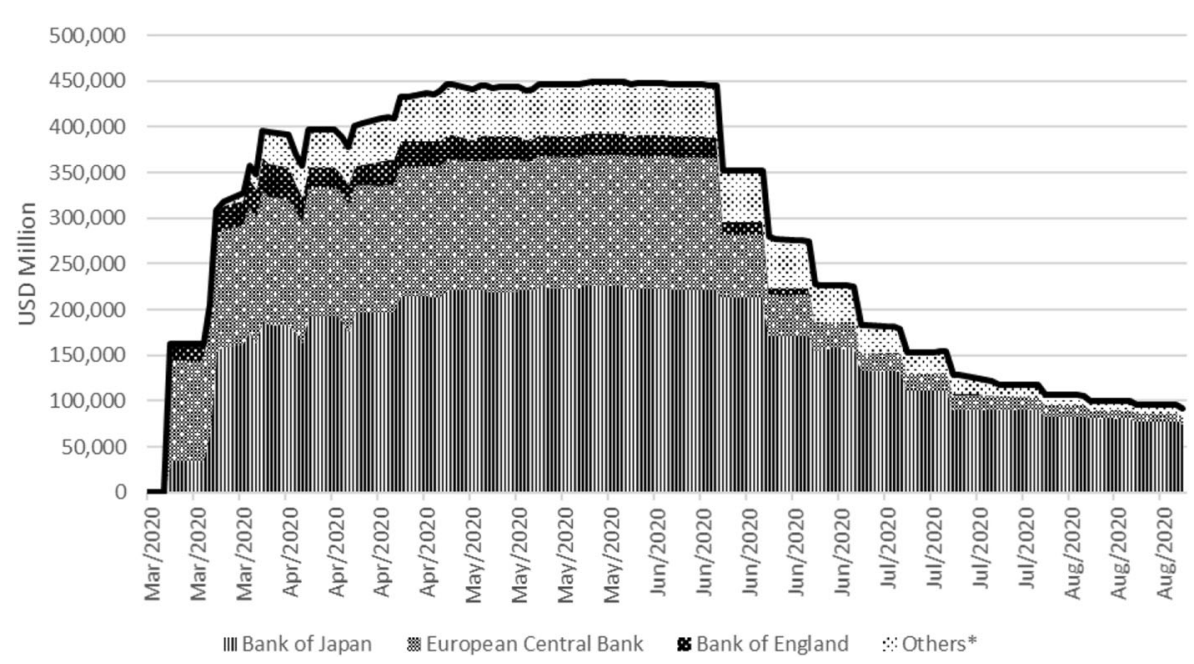

Fig. 5 US Dollar Liquidity Swaps by Central Bank 2020- Total Amount Outstanding- (USD million). Others: Bank of Canada, Swiss National Bank, Reserve Bank of Australia, Danmarks Nationalbank, Norges Bank, Monetary Authority of Singapore, Banco Central Do Brasil, Bank of Korea, Banco de Mexico, Reserve Bank of New Zealand, Sveriges Riksbank. Source: Federal Reserve Bank of New York, Own Calculations

As in the GFC, these policies quickly allayed the funding pressure in the countries with access to the swap lines in comparison to those which did not have such access. (See Fig. 6).

Thus the Fed greatly expanded the scope of international monetary cooperation and its international lender of last resort role. Other large important central banks also have swap line networks with other countries that they are connected to. However, there are a number of countries which for various (often political) reasons do not have access to the swap network. A number of commentators have suggested possible reforms involving the IMF that could extend the swap network and create a truly global financial safety net.

Some have suggested that SDRs be used to back swap access (O'Neill and Lombardi 2020). Others have suggested that the IMF could underwrite the swap lines as they did in the 1960s to secure a dollar swap line for the UK (McCauley and Schenk 2020). Collins et al. (2020) as well as Reis (2019) advocate expanding the IMF's financial resources to fight the pandemic and that the major central banks should link their swap lines to it. Levy Yeyati (2020) views the IMF as the dealer between the funding central bank and the borrowing country or as a central bank clearing house. Velasco (2020) makes the case for the IMF, the World Bank and the regional development banks to establish a special purpose vehicle (SPV) that would issue bonds to be purchased by leading central banks. In this vein, Brunnermeier and Huang (2018) propose a global synthetic safe asset (SBBS) that each country would set up. The SPV would tranche the country's sovereign debt into junior and senior bond, in which the junior bond would absorb losses and protect the senior bond.

Finally, Eichengreen (2020) proposes that we revisit J.M. Keynes idea that the IMF become a global central bank that issues bancor, a global currency. Whether any of these proposals will ever be adopted is an interesting question. 
a

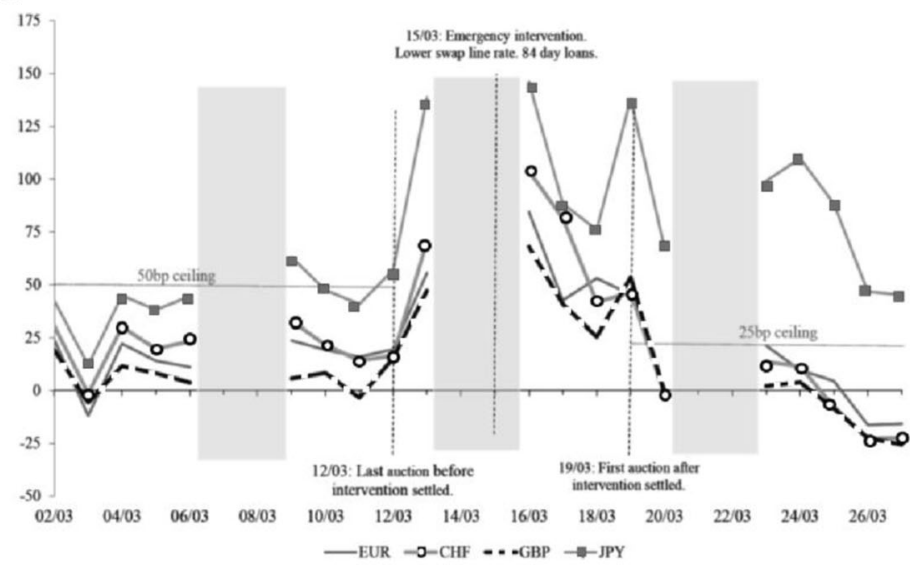

b

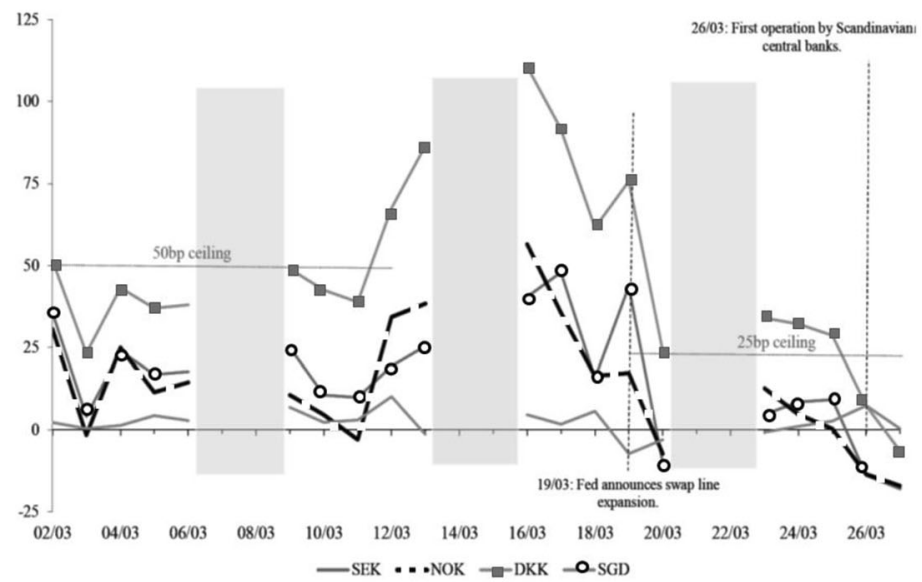

C

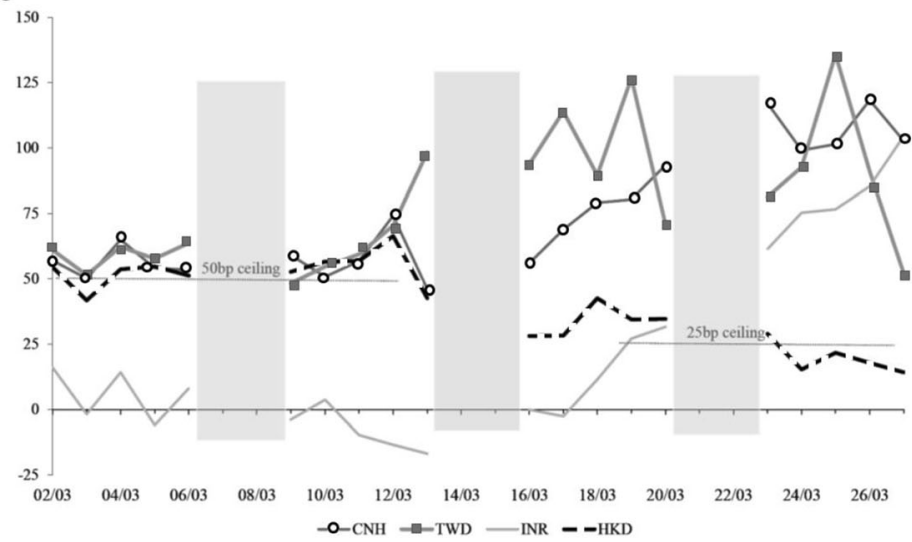

Fig. 6 CIP Deviations and Fed Swap Intervention Spring 2020. Source: Figs. 1, 2 and 5 McCauley and Schenk (2020). Central bank swap lines during the covid-19 pandemic. Covid Economics, 2 


\section{Conclusions}

A number of conclusions follow from this survey;

1. Monetary policy cooperation generally is successful when done in a rules based environment. This was the case under the Gold Standard and in the Great Moderation. Cooperation in these regimes was done for technical or Lender of Last Resort reasons and supported the communication needed to develop a shared consensus about what rule was best.

2. Monetary policy cooperation does not work when domestic and international policy priorities are inconsistent, i.e. when an international policy rule (e.g. exchange rate stability) conflicts with domestic goals of price stability or full employment. Thus, the agreed international rules conflicted with domestic priorities during the interwar gold exchange standard, the Bretton Woods System and the early 1980s. Under the classical gold standard and during the Great Moderation, by contrast, the nominal anchor rules were consistent with price stability.

3. It follows that short term efforts at international monetary policy coordination do not work when they involve a departure from domestic policy fundamentals e.g. Long Island 1927 and the Plaza and Louvre Accords.

4. The coordinated rescues of the emerging countries in the financial crises of the 1990s were mainly bailouts and were not based on Bagehot's principles. This promoted future risky behavior. Moreover, in a number of cases the recipients did not graduate to the monetary policy strategies of the advanced countries, leading to later instability. Recent cooperation, largely through the BIS, has helped to create an epistemic community of central banks that has learned to follow rules based policy. This has been beneficial but may be challenged by the addition of new members to the BIS governing board and by the proliferation of multi-agency groups.

5. The use of swaps, earlier developed in the 1960s, by the Federal Reserve and other advanced country central banks to allay the international liquidity crisis of both the GFC and the Covid 19 pandemic crises was a perfect example of central bank cooperation. Extending the network to all emerging countries would create a global financial safety net.

6. A return to a rules based system under floating exchange rates once the Covid 19 Crisis is long past would provide an environment conducive to stable economic growth and low inflation for the world as was the case during the Great Moderation.

The evolution of central bank cooperation and coordination since the classical gold standard has closely followed the evolution of central bank credibility (Bordo and Siklos 2014, 2016). Under the classical gold standard central banks had high credibility because the gold standard rule was primarily a domestic rule and the international gold standard rule followed from that (Bordo and Kydland 1995). Central bank cooperation was perfectly consistent with that arrangement. In the Great Moderation, central banks enjoyed high credibility because under floating exchange rates they learned to follow domestic rules based policy focused on price stability and had the independence to pursue their targets consistently. 
But in the intervening seven decades, central bank credibility declined because the underlying theoretical and political economy framework dramatically changed towards maintaining domestic aggregate demand and full employment along with fixed exchange rates and the gold convertibility rule- an impossible task, which became evident in the interwar and later in the Bretton Woods era, even with capital controls. Central bank cooperation and coordination was effectively used to prop up the Bretton Woods system through short term fixes, but ultimately these regimes were doomed by the growing inconsistency of policy goals. It took the strains of the Great Inflation to create the learning environment to restore central bank credibility and identify a sustainable rule based on domestic monetary policy.

However, since the GFC the use by all central banks of quantitative easing and forward guidance has led to a departure from rules based monetary policy towards discretion. In the international sphere this has led to increased spillovers across countries and a return to the threat of competitive devaluations of the 1930s and currency wars.

Whether we can return to the normal world before the GFC of small central bank balance sheets, normalized interest rates and the policy rate as the instrument is an open question.

In the face of a global financial crisis as in 2007-2008 and 2020 central banks have learned to effectively cooperate to prevent a liquidity panic using the swap network to pursue the well-known tenets of Bagehot's rules. The international swap network is a step in the direction of a global financial safety net. The disastrous experience of the 1930s may have led them to do the right thing.

\section{References}

Ahamed L (2009) Lords of finance: the bankers who broke the world. Penguin, New York

Bahaj S, Reis R (2019) Central bank Swap Lines: Evidence on the Effect of the Lender of Last Resort Institute for Monetary and Economic Studies. Bank of Japan Discussion Paper No. 2019-E-9

Bahaj S, Reis R (2020) Central bank swap lines during the Covid 19 pandemic. Covid Econ Issue 2 April 8 Bordo M (1993) The Bretton woods international monetary system: a historical overview. In: Bordo MD, Eichengreen B (eds) A Retrospective on the Bretton Woods System: Lessons for International Monetary Reform. University of Chicago Press, Chicago, pp 3-108

Bordo M, Kydland F (1995) The gold standard as a rule. Explor Econ Hist 32:423-464

Bordo M, McCauley R (2019) Triffin: dilemma or myth IMF Economic Review. July

Bordo M and Meissner C (2016) Fiscal and financial crises NBER working paper 22059, March

Bordo M, Schenk C (2016) Monetary policy cooperation and coordination: an historical perspective on the importance of rules. In: Bordo MD, Taylor J (eds) Rules for international monetary stability: past, present, and future. Hoover Institution Press

Bordo M, Schwartz AJ (1999) Under what circumstances past and present, have international rescues of countries in financial distress been successful? J Int Money Finance 18(4):683-708

Bordo M, Schwartz AJ (2000) Measuring real economic effects of bailouts: historical perspectives on how countries in distress have fared with and without bailouts. Carn-Roch Conf Ser Public Policy 53:81-16

Bordo M, Siklos P (2019) The Transformation and Performance of Emerging Market Economies Across the Great Divide of the Global Financial Crisis NBER Working Paper 26342

Bordo M, Humpage O, Schwartz A (2015) Strained relations: US foreign exchange operations and monetary policy in the twentieth century. University of Chicago Press, Chicago

Bordo M, Naef A, Monnet E (2019) The Gold Pool (1961-1968) and the Fall of the Bretton Woods System: Lessons for Central bank Cooperation J Econ Hist Vol 79 Issue 4 
Borio C, Toniolo G (2005) One Hundred and Thirty Years of Central Bank Cooperation: A BIS Perspective BIS working paper 197

Boughton J (2012) Tearing Down Walls; the IMF 1990-1999. IMF, Washington D.C.

Brunnermeier MK, Huang L (2018) A Global Safe Asset for and from Emerging Market Economies Princeton University (mimeo)

Chen K, Mancini-Griffoli T, Sahay R, (2014) Spillovers from US monetary policy on emerging markets: different this time? IMF working paper 240

Clarke SVO (1967) Central bank Cooperation 1924-31 Federal Reserve Bank of New York

Collins C, Potter S, Truman E (2020) Enhancing Central bank Cooperation in the Covid 19 Pandemic Peterson Institute for International Economics April 9

Despres E, Kindleberger C, Salant W (1966) The Dollar and World Liquidity: A Minority view Economist 5 February, pp 526-529

Dominguez K, Frankel J (1993) Does Foreign Exchange Intervention Work? Institute for International Economics, Washington DC

Eichengreen B (1992) Golden Fetters. Oxford University Press, New York

Eichengreen B (2010) Exorbitant privilege: the rise and fall of the Dollar and the future of the international monetary system. Oxford University Press, New York

Eichengreen B (2013) International policy coordination: the long view. In: Feenstra R, Taylor AM (eds) Globalization in an age of crisis: multilateral economic cooperation in the twenty-first century. University of Chicago Press, Chicago, pp 43-82

Eichengreen (2020) Dollar Sensationalism Project Syndicate August 18

Eichengreen B, Flandreau M, Mehl A, Chitu L (2016) 'International currencies past, Present and Future: Two views from Economic History' (mimeo)

Emminger O (1967) Practical Aspects of the Problem of Balance of Payments Adjustment. J Polit Econ 75 9: $512-522$

Feldstein M (1986) New evidence on the effects of exchange rate interventions NBER working paper 2052

Flandreau M (1987) Central bank cooperation in historical perspective: a skeptical view. Aust Econ Hist Rev 50(4):735-763

Frankel J (2016) The plaza accord 30 years later. In: Bergsten CF, Green RA (eds) International Monetary Cooperation: Lessons from the Plaza Accord After Thirty Years. Peterson Institute for International Economics, Washington DC, pp 53-72

Friedman M (1953) The Case for Floating Exchange Rates' in Milton Friedman, Essays in Positive Economics. University of Chicago Press, Chicago, pp 157-203

Garber P (1993) The collapse of the Bretton woods fixed exchange rate system. In: Bordo M, Eichengreen B (eds) A retrospective on the Bretton woods system: lessons for international monetary reform. University of Chicago Press, Chicago, pp 461-494

Giovannini A (1993) Bretton woods and its precursors: rules versus discretion in the history of international monetary regimes. In: Bordo M, Eichengreen B (eds) . A Retrospective on the Bretton Woods System: Lessons for International Monetary Reform, Chicago

Goodhart C (2011) The Basel committee on banking supervision; a history of the early years, Cambridge

Humpage O (1988) 'Intervention and the Dollar's decline' Federal Reserve Bank of Cleveland. Econ Rev 2492:2-16

International Monetary Fund (2011) 'Did the Plaza Accord Cause Japan's Lost Decades?' World Economic Outlook Box1.4, (April)

Irwin D (2013) The French gold sink and the great deflation. Cato Pap Public Policy 2:3-45

James H (2016) International cooperation and central banks In Y. Cassis, R. Grossman and C.R. Schenk, eds., Oxford Handbook of Banking and Financial History, Oxford

Keynes JM (1943) Proposals for an International Clearing Union. In: Horsefield JK (ed) (1969)The International Monetary Fund, 1945-1965: Twenty Years of International Monetary Cooperation, vol 3, Documents. International Monetary Fund, Washington DC, pp 19-36

Levy Yeyati E (2020) Covid, Fed Swaps and the IMF as Lender of Last Resort VoxEU March 31

McCauley RN (2015) Does the US dollar confer an exorbitant privilege? J Int Money Financ 57:1-14

McCauley RN, Schenk CR (2015) Reforming the international monetary system in the 1970s and 2000s: would an SDR substitution account have worked? Int Finance 18(2):187-206

McCauley RN, Schenk C (2020) Central bank Swaps Then and Now: Swaps and Dollar Liquidity in the 1960s BIS Working Paper 851 April

Meltzer A (2003) A history of the Federal Reserve Vol 1: 1913-1951. University of Chicago Press, Chicago

Reis R (2019) A solution to sudden stops: the IMF and central banks should work together to resolve financial crises Finance and Development, June 
Rueff J (1961) The west is risking a credit collapse, Fortune, July

Schenk CR (2010) The decline of Sterling: managing the retreat of an international currency 1945-92, Cambridge University Press

Schenk CR (2015) China and the International Monetary Fund 1945-1985. In: Yago K, Asai Y, Itoh M (eds) History of the IMF: organization. Springer, Policy and Market, pp 275-309

Schenk CR (2016) Coordination failures during and after Bretton woods. In: Qureshi M, Ghosh A (eds) From Great Depression to Great Recession: The Elusive Quest for International Policy Cooperation. International Monetary Fund, Washington D.C. (forthcoming)

Schenk CR, Straumann T (2016) International monetary policy regimes: historical perspectives. In: Bordo M, Eitrheim O, Flandreau M, Qvigstad J (eds) Central banks at a crossroad: what can be learned from history. Cambridge University Press, New York (in press)

Taylor J (1985) International coordination in the Design of Macroeconomic Policy Rules. Eur Econ Rev 28: 53-81

Taylor J (2016) A rules based cooperatively managed international monetary system for the future. In: Bergsten CF, Green RA (eds) International Monetary Cooperation: Lessons from the Plaza Accord After Thirty Years. Peterson Institute for International Economics, Washington DC, pp 217-236

Toniolo G, Clement P, (2005) Central Bank cooperation at the Bank for International Settlements, 1930-1973, Cambridge University Press

Tooze A (2018) Crashed: How a Decade of Financial Crises Changed the World London: Penguin Triffin R (1960) Gold and the Dollar crisis. Yale University Press, New Haven

Velasco A (2020) Preventing an emerging market meltdown Project Syndicate June 9

Publisher's Note Springer Nature remains neutral with regard to jurisdictional claims in published maps and institutional affiliations. 